\title{
Assessment of Hydraulic Floor Crane
}

\author{
Ajit Bhoyar', Akshay Sonule ${ }^{2}$, Abhishek Naik ${ }^{3}$, Jai Shankar $^{4}$, Suhas Wankhede ${ }^{5}$, \\ Nitin Sawarkar ${ }^{6}$ \\ ${ }^{1,2,3,4}$ U.G. Student, Wainganga College of Engineering and Management, Maharashtra, India \\ ${ }^{5,6}$ Asst Professor, Wainganga College of Engineering and Management, Maharashtra, India
}

\begin{abstract}
In this research work, the modification of floor hydraulic crane was carried out. The modified floor hydraulic crane has the following parts; base plate/truck/pallet, battery seat, boom and lifting switches, vertical column, horizontal arm, secondary horizontal arm, power screw, roller, hook, nuts and bolts. The selections of materials for the various components were based on the strength, machinability, toughness, ductility, and hardness. It was designed for load of 50 to $100 \mathrm{~kg}$ capacities and the development of suitable.
\end{abstract}

Keywords- Crane, Material

\section{I- INTRODUCTION}

$\mathbf{T}$ hese hydraulic floor cranes provide an efficient, low cost alternative to other material handling equipment's. Strong, robust, sturdy and built to very standard, these cranes are manually variable in loading, unloading and shifting of heavy loads.

Crane structure consists of chassis, vertical column, horizontal arm, and the hydraulic pump with cylinder assembly. The box crane can take heavy loads effectively, avoids damage under rough and unskilled handling. Avoids damage under rough and unskilled handling. The hydraulic cranes used in the industry are efficient but they only have the ability to lift the load and put it down at some other position.

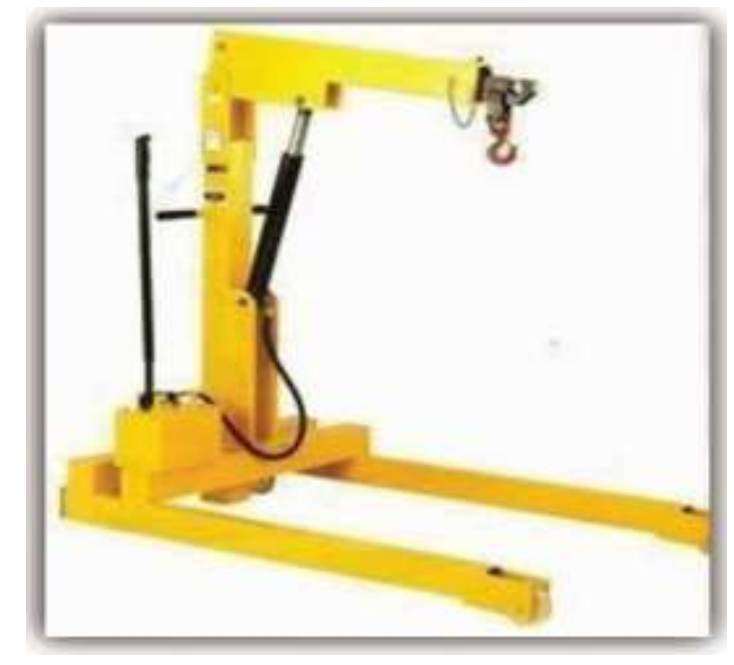

Fig 1-Hydraulic Floor Crane

\section{II- LITERATURE REVIEW}

Material Handling is the movement, storage, control and protection of materials, goods and products throughout the process of manufacturing, distribution, consumption and disposal. The focus is on the methods, mechanical equipment, systems and related controls used to achieve these functions. Hydraulic cranes are an important part of the material handling equipment's. The hydraulic cranes that are being used work on manual power.

\section{Basicparts of Hydraulic Crane:}




\section{International Journal of Innovations in Engineering and Science, www.ijies.net}

\section{Base plate/ Truck/Pallet}

It is a plate that serves as a base or support. It is used for carrying the overall weight of the project. It is made of mild steel. In this 4 bars are welded by using Electric Arc Welding to give it a rectangular shape. It is made up of cast iron.

\section{Pulleys}

A pulley is a wheel on an axle that is designed to support movement and change of direction of a cable or belt along its circumference. Pulleys are used in a variety of ways to lift loads, apply forces, and to transmit power.

\section{Vertical column:-}

This is mounted on the pallet/base plate/truck in longitudinal or $\mathrm{Y}$ - direction. It consists of a short handle which is welded to the vertical column for $360^{\circ}$ rotation of the column so that the load can be dropped at the required position

\section{Thrust ball bearings}

Ball bearings are called as 'anti friction bearings'.This is a misnomer because friction is always present in such bearings, mainly owing to rolling resistance, between the balls or rollers and the race. It carries the vertical thrust and axial load.

\section{Horizontal arm: -}

$$
\text { It IS fixed horizontal }
$$
arm on which our hydraulic piston and cylinder is mounted. It is fixed with the vertical column with welded joint which can rotate with the rotating vertical column to $360^{\circ}$ rotation.

\section{Hook:}

Hook is fixed with the cable moving on pulleys. Hook is used for attaching the load to horizontal arm which moves up and down due which the connected loads are lifted and rotates.

7. Nuts and Bolts:

Nuts and bolts are the hardware fasteners which are used to fasten thevarious different parts .in our project we have used around 20 nut and bolts.

\section{Wheels:}

A wheel is a circular component that is intended to rotate on an axial bearing. The wheel IS one of the mam components of the wheel and axle which is one of the six simple machines. Wheels, in conjunction with axles, allow heavy objects to be moved easily facilitating movement.

\section{Hydraulic jack}

A hydraulic j a ck is a jack that uses a liquid to push against a piston. This is based on Pascal's Principle. The principle states that pressure in a closed container is the same at all points. If there are two cylinders connected, applying force to the smaller cylinder will result in the same amount of pressure in the larger cylinder.

\section{Application of Cranes}

1. Its used for lifting,carrng and shifting operation in small, medium and large industries.

2. These type of cane used for foundry welding workshop, Automobile workshop and Construction sites

\section{Manufacturing:-}

The hydraulic crane which was manufactured has 12 parts. They are Base Plate/Truck/Pallet,H ydraulic Jack, Hydraulic hose, Vertical column, Ball bearing, Horizontal arm, Roller, Hook, Nuts and Bolts, Wheels, pulleys, cable, handle. Base plates are made of caste iron metal rod.

The rods are cut according to the dimensions and they are welded using metal arc welding. Then bearing was selected according to the thrust and axial load and vertical column are fitted on the bearing so that it can rotate to a $360^{\circ}$. The horizontal arm is hinged and contains pulley in it so that hook can travel up and down. Hydraulic system is selected according to the power required.

\section{Assembly:-}

1. Arrangement of four wheels on the four the base plate.

2. Assembly of fixture for holding the bearing and the vertical column.

3. Assembly horizontal arm.

4. Assembly of hydraulic jack.

5. Connection of hoses with the hydraulic Jack.

6. Installing Pulleys in horizontal and vertical arm.

7. Attaching a hook on the high steelcable. 


\section{International Journal of Innovations in Engineering and Science, www.ijies.net}

\section{III- DESIGN AND CALCULATION}

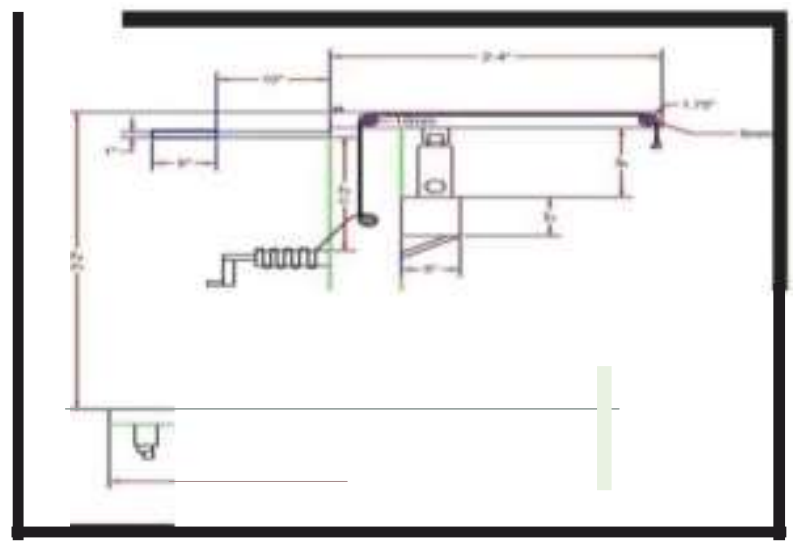

Calculation of floor load :-

Floor load is a measure of pressure on the floor of truck. It isnecessary to avoid the catastrophic failure.

Total weight $=50 \mathrm{~kg}$

Length $=100 \mathrm{~cm}=1.00 \mathrm{~m}$

Breadth $=56 \mathrm{~cm}=0.56 \mathrm{~m}$

Floor load $=$ total weight/total floor area

$$
\begin{aligned}
& =\mathrm{W} \mathrm{I}(1 * \mathrm{~b}) \\
& =50 \mathrm{I}(1.00 * 0.56) \\
= & 89.2870 \mathrm{~kg} / \mathrm{m} 2 \text { or } 89.2870 \mathrm{~N}
\end{aligned}
$$

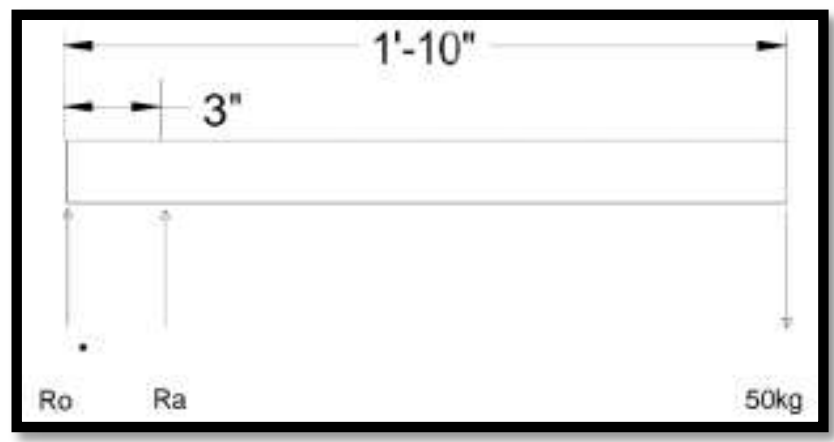

\section{FORCES ON CYLINDER}

\section{At middle position-}

$\mathrm{Mo}=5000 * 560-\mathrm{RA} * 77=0$

$\mathrm{RA}=36363.63 \mathrm{~N}$

Reaction in the direction of cylinder will be given by

$\mathrm{R}$ cylinder $=\mathrm{RA}$

$\mathrm{R}$ cylinder $=36363.63$

$\mathrm{R}$ cylinder $=36363.63 \mathrm{NN}$

$$
\mathrm{Ro}=41363.63 \mathrm{~N}
$$

\section{At upper position-}

Mo $=0$
$\mathrm{Mo}=5000 *(560 \cos 45)+\mathrm{RA} *(77 \cos 45)$

$\mathrm{RA}=-36363.63 \mathrm{~N}$

Reaction in the direction of cylinder will be given by

$\mathrm{R}$ cylinder $=\mathrm{RA}(\cos 15)$

$\mathrm{R}$ cylinder $=-35124.56 \mathrm{~N}$

Ro $=-40124.56 \mathrm{~N}$

\section{Calculation For Crane Stability}

\section{Forces on part one-}

Load applied to the arm at the hook is $50 \mathrm{~kg}$ i.e $=$ $50 * 9.81$

$$
=490.5 \mathrm{~N}
$$

Volume of overhanging arm $=\mathrm{L} * \mathrm{~B} * \mathrm{H}$

$$
\begin{aligned}
& =283.2 * 20 * 51.50 \\
& =291696 \mathrm{cu} \mathrm{mm} \\
& =.000291696 \mathrm{cum}
\end{aligned}
$$

Density of material used $=7850 \mathrm{~kg} / \mathrm{cuM}$

Mass of the overhanging arm

$$
\begin{aligned}
& =\text { Volume } * \text { Density } \\
& =0.000291696 * 7850 \\
& =2.2898 \mathrm{~kg}
\end{aligned}
$$

Weight of the overhanging arm

$$
\begin{aligned}
& =2.2898 * 9.81 \\
& =22.4630 \mathrm{~N}
\end{aligned}
$$

\section{Force On Part Two-}

Volume ofremaining arm $=\mathrm{L} * \mathrm{~B} * \mathrm{H}$

$$
\begin{aligned}
& =258 * 20 * 51.50 \\
& =265740 \mathrm{cu} \mathrm{mm} \\
& =.000265740 \mathrm{cu} \mathrm{m}
\end{aligned}
$$

Density of material used $=7850 \mathrm{~kg} / \mathrm{cu} \mathrm{m}$ Mass of the remaining arm

$$
\begin{aligned}
& =\text { Volume } * \text { Density } \\
& =0.000265740 * 7850 \\
& =2.08605 \mathrm{~kg}
\end{aligned}
$$

Weight of remaining arm

$$
\begin{aligned}
& =.000265740 * 9.81 \\
& =20.4642 \mathrm{~N}
\end{aligned}
$$

\section{Force on part three-}

$$
\begin{aligned}
\text { Volume of column } & =\mathrm{L} * \mathrm{~B} * \mathrm{H} \\
& =1000 * 18820.527 \\
& =18820527.60 \mathrm{cumm} \\
& =0.018820527 \mathrm{cu} \mathrm{m}
\end{aligned}
$$

Density of material used $=7850 \mathrm{~kg} / \mathrm{cuM}$ Mass of the column $=$ volume $*$ Density 
Vol. 6, No. 7, 2021, PP. 33-37

\section{International Journal of Innovations in Engineering and Science, www.ijies.net}

$$
\begin{aligned}
& =0.018820527^{*} \\
& =147.77 \mathrm{~kg}
\end{aligned}
$$

Weight of the column $=147.77 * 9.81$

$$
=1449.3406740 \mathrm{~N}
$$

\section{Force on part four-}

Volume of base $=\mathrm{L} * \mathrm{~B} * \mathrm{H}$

$$
\begin{aligned}
& =620 * 20 * 51.50 \\
& =638600 \mathrm{cu} \mathrm{mm} \\
& =0.000638600 \mathrm{cu} \mathrm{m}
\end{aligned}
$$

Density of material used $=7850 \mathrm{~kg} / \mathrm{cu} \mathrm{m}$

Mass of the base $=$ volume*Density

$$
\begin{aligned}
& =0.0315 * 7850 \\
& =5.0130 \mathrm{~kg}
\end{aligned}
$$

Weight of the base $=5.0130 * 9.81$

$$
=5 \mathrm{O} \mathrm{N}
$$

\section{Force on part five-}

Volume of base arm $=\mathrm{L} * \mathrm{~B} * \mathrm{H}$

$$
\begin{aligned}
& =1000 * 20 * 51.50 \\
& =1030000.00 \mathrm{cu} \mathrm{mm}
\end{aligned}
$$

Density of material used $=7850 \mathrm{~kg} / \mathrm{cu}$

Mass of base arm $=$ volume $*$ Density

$$
=8.085500 \mathrm{~kg}
$$

Weight of the base arm

$$
\begin{aligned}
& =8.085500 * 9.81 \\
& =79.3187 \mathrm{~N}
\end{aligned}
$$

\section{DESIGN OF CYLINDER}

Assuming the internal pressure,

$$
(\mathrm{Pi})=110 \mathrm{~N} / \mathrm{mm} 2
$$

Material used for cylinder is Mild steel

$$
=226
$$

Yield strength of mild steel $=250 \mathrm{~N} / \mathrm{mm} 2$

Ultimate tensile strength of mild steel

$$
=410 \mathrm{~N} / \mathrm{mm} 2
$$

Factor of safety $=1.5$ (assumed)

$$
\begin{aligned}
\mathrm{Pi} & =\mathrm{FIA} \\
\mathrm{A} & =\mathrm{F} / \mathrm{Pi} \\
& =35124 / 110 \\
\mathrm{~A} & =319.30 \mathrm{~mm} 2
\end{aligned}
$$

But, $A=(\# / 4) d 2$

$$
=319.30
$$$$
\mathrm{D}=20.16 \mathrm{~mm}
$$

Using cylinder of standard diameter,

$$
\text { Bore diameter }=20 \mathrm{~mm}
$$

$\#=$ PIA(3.1415926)

Now, allowable tensile strength crall

$$
\begin{aligned}
& \text { Syt/ FOS } \\
= & 79.3187 \mathrm{~N}
\end{aligned}
$$

Allowable shear stress Tall $=$ Ssy $/$ FOS

Ssy $=$ Yield strength in shear of the cylinder material, $\mathrm{N} / \mathrm{mm} 2$

$$
\begin{aligned}
\text { Tall } & =0.5 \text { Syt } / \text { FOS } \\
& =0.5 * 250 / 1.5 \\
& =83.33 \mathrm{~N} / \mathrm{mm} 2
\end{aligned}
$$

\section{IV- CONCLUSION}

The aim of our project was to build a fully functional HYDRAULIC FLOOR CRANE Mechanism which is capable of lifting load up to $50 \mathrm{~kg}$ with the hook and pulley system and a load of $105+\mathrm{kg}$ from the hook attached to the horizontal arm . We accurately achieved our first goal of lifting the load from both the hooks and $360^{\circ}$ rotary motion of the vertical column as well as up and down movement of the horizontal arm. We feel that our design and fabrication was a great success both in terms of strength and stiffness. Our project weighed $60 \mathrm{~kg}$ which is capable of lifting load up to $150 \mathrm{~kg}$ using hydraulic power.

\section{Features :}

Overload safety

Lifting/lowering speed control

Position holding by check valve

Hydro-mechanical lock

Hose burst safety valves

Electrical safety interlocks

Simple to use and maintain

Compact structure

\section{REFERENCES}

[1] Arun Kumar N., Srinivasan V., Krishna Kumar P., Analysing the strength of unidirectional fibre orientations under transverse static load, International Journal of Applied Engineering Research, v-9, i-22, pp7749-7754, 2014.

[2] Srinivasan V., Analysis of static and dynamic load on hydrostatic bearing with variable viscosity and pressure, Indian Journal of Science and Technology, v-6, $i$ SUPPL.6, pp-4777-4782, 2013. 


\section{International Journal of Innovations in Engineering and Science, www.ijies.net}

[3] Srinivasan V., Optimizing air traffic conflict and congestion using genetic algorithm, Middle - East Journal of Scientific Research, v-20, i-4, pp-456-461, 2014.

[4] Praveen R., Achudhan M., Optimization of jute composite as a noise retardant material, International Journal of Applied Engineering Research, v-9, i-22, pp7627-7632, 2014.

[5] Raja Kumar G., Achudhan M., Srinivasa Rao G., Studies on corrosion behaviour of borated stainless steel (304B) welds, International Journal of Applied Engineering Research, v-9, i-22, pp-7767-7772, 2014.

[6] Ganeshram V., Achudhan M., Design and moldflow analysis of piston cooling nozzle in automobiles, Indian Journal of Science and Technology, v-6, i-SUPPL.6, pp4808-4813, 2013.

[7] Ganeshram V., Achudhan M., Synthesis and characterization of phenol formaldehyde resin as a binder used for coated abrasives, Indian Journal of Science and Technology, v-6, i-SUPPL.6, pp-4814-4823, 2013.

[8] Achudhan M., Prem Jayakumar M., Mathematical modeling and control of an electricallyheated catalyst, International Journal of Applied Engineering Research, $v$ 9, i-23, pp-23013-, 2014.

[9] Anbazhagan R., Satheesh B., Gopalakrishnan K., Mathematical modeling and simulation of modern cars in the role of stability analysis, Indian Journal of Science and Technology, v-6, i-SUPPL5, pp-4633-4641, 2013.

[10] Udayakumar R., Kaliyamurthie K.P., Khanaa, Thooyamani K.P., Data mining a boon: Predictive system for university topper women in academia, World Applied Sciences Journal, v-29, i-14, pp-86-90, 2014.

[11] Kaliyamurthie K.P., Parameswari D., Udayakumar R., QOS aware privacy preserving location monitoring in wireless sensor network, Indian Journal of Science and Technology, v-6, i-SUPPL5, pp-4648-4652, 2013.

[12] Kumar J., Sathish Kumar K., Dayakar P., Effect of microsilica on high strength concrete, International Journal of Applied Engineering Research, v-9, i-22, pp5427-5432, 2014.

[13] Dayakar P., Vijay Ruthrapathi G., Prakesh J., Management of bio-medical waste, International Journal of Applied Engineering Research, v-9, i-22, pp-55185526, 2014.

[14] RK Rajpoot- Text book of Machine Component \& Design

[15] Nitin Sawarkar, K.S. Zakiuddin, "Analysis Of Three Jaw Type Flexible Clutch”, Zeichen Journa, Vol. 6, Issue 11, Pg. 180-188, Dec 2020.

[16] Nitin Sawarkar, Lokesh D. Mankar, Dr .Bharat Chede, Swapnil Choudhary "Investigation of Pipe Inspection Robot by using Commercial Package”, Turkish Journal of Computer and Mathematics Education (TURCOMAT) ,Vol. no. 12, Issue 13, Pg.2264-2269, June 2021. 